\title{
Congo Red Decolorization and Detoxification by Aspergillus niger: Removal Mechanisms and Dye Degradation Pathway
}

\author{
Nedra Asses (D), Lamia Ayed, Neila Hkiri, and Moktar Hamdi \\ LR-Microbial Ecology and Technology, INSAT, University of Carthage, Tunis, Tunisia \\ Correspondence should be addressed to Nedra Asses; nedra.asses@gmail.com
}

Received 10 May 2018; Accepted 25 July 2018; Published 6 August 2018

Academic Editor: Chedly Chouchani

Copyright (C) 2018 Nedra Asses et al. This is an open access article distributed under the Creative Commons Attribution License, which permits unrestricted use, distribution, and reproduction in any medium, provided the original work is properly cited.

\begin{abstract}
Congo red is one of the best known and used azo dyes which has two azo bonds $(-\mathrm{N}=\mathrm{N}-)$ chromophore in its molecular structure. Its structural stability makes it highly toxic and resistant to biodegradation. The objective of this study was to assess the congo red biodegradation and detoxification by Aspergillus niger. The effects of $\mathrm{pH}$, initial dye concentration, temperature, and shaking speed on the decolorization rate and enzymes production were studied. The maximum decolorization was correlated with lignin peroxidase and manganese peroxidase production. Above $97 \%$ were obtained when $2 \mathrm{~g}$ mycelia were incubated at $\mathrm{pH} 5$, in presence of $200 \mathrm{mg} / \mathrm{L}$ of dye during 6 days at $28^{\circ} \mathrm{C}$ and under 120 to $150 \mathrm{rpm}$ shaking speed. The degraded metabolites were characterized by using LC-MS/MS analyses and the biodegradation mechanism was also studied. Congo red bioconversion formed degradation metabolites mainly by peroxidases activities, i.e., the sodium naphthalene sulfonate $(\mathrm{m} / \mathrm{z}=227)$ and the cycloheptadienylium (m/z =91). Phytotoxicity and microtoxicity tests confirmed that degradation metabolites were less toxic than original dye.
\end{abstract}

\section{Introduction}

Water is necessary to sustaining life on earth. However, available water represents less than $1 \%$ of the total volume of fresh water on earth [1]. However, pollution reduces its availability for human use. The water pollutants are usually generated by industries and can be divided into various classes. Every class has its own specific dangers.

The textile industry is one of the most polluting industries of clean water. In fact, during the manufacturing processes, a large percentage of the synthetic dye does not bind and is lost in wastewaters, which are usually discharged untreated. Congo red is the most common dyes that can be found in textile industry. It is a benzidine based anionic diazo dye [2]. This dye is known to be metabolized into benzidine, which is a human carcinogen and mutagen; that is why it is banned in many countries.

Various chemical and physical methods of these colored waste waters have been proposed in the last few decades such as coagulation-flocculation, oxidation, and electrochemical methods [3]. Nowadays scientists work on the implementation of innovative processes to treat these recalcitrant compounds. Among the most recent treatments is the advanced oxidation process (AOP), which allows mineralization of toxic organic molecules through formation of extremely reactive and nonselective radicals such as hydroxyl radicals. However, AOP have many disadvantages, such as highenergy costs and sometimes formation of toxic by-products [4].

However, bioprocessing can be considered as a preferred option to overcome these disadvantages because it is cost saving and environmentally friendly. Biological treatments can be used to degrade and/or to adsorb azo dyes contaminants [5]. The most efficient microorganisms to break down colored pollutants so far reported are white-rot fungi. These comprise mostly basidiomycetous fungi, which are capable of extensive aerobic lignin degradation and mineralization. This is possible through several extracellular lignin-degrading enzymes [6], such as lignin peroxidase, manganese-dependent peroxidase, and laccase. A previous report showed dye degradation potential of Aspergillus niger [7]. A total decolorization of Procion Red MX-5B by Aspergillus niger was obtained after $336 \mathrm{~h}$ of treatment. On the other hand, the enzymatic cleavage of azo dyes leads to the formation of toxic products, mainly amines. Therefore, it is important to identify and evaluate toxicity of degradation products [8]. 
The aim of the present work was to study the Aspergillus niger potential for detoxification and decolorization of $\mathrm{CR}$ dye. The enzymes involved in the decolorization process were identified and the effects of various parameters $(\mathrm{pH}$, temperature, initial dye concentration, and shaking speed) on dye decolorization and enzymes production were investigated. The degraded metabolites were characterized by using LCMS/MS analyses. The study also aimed to assess the toxicity of the metabolites formed after the degradation of CR dye by this fungus.

\section{Materials and Methods}

2.1. Fungal Strain and Biomass Generation. Aspergillus niger was isolated from processing wastewater [9]. The fungal strain was maintained on Potato Dextrose Agar (Merck) at room at $28 \pm 2^{\circ} \mathrm{C}$. To generate biomass, three mycelia plugs $(0.7 \mathrm{~cm}$ diameter) taken from the edge of the colony were transferred into $100 \mathrm{ml}$ synthetic nutrient broth medium containing $\left(\mathrm{g}\right.$. $\left.\mathrm{L}^{-1}\right)$ glucose $10 \mathrm{~g}$, yeast extracts $1 \mathrm{~g}$, and peptone $2 \mathrm{~g}$ (Scharlau). The $\mathrm{pH}$ was adjusted to $6.0 \pm 0.2$ and the culture was incubated for 8 days at $30^{\circ} \mathrm{C}$. The fungal biomass was homogenized, filtered through Whatman filter paper No. 1, and washed with sterile distilled water. This freshly prepared biomass was used for dye biodegradation experiments.

2.2. Condition Optimization for CR Decolorization. The fungus ability to decolorize the CR dye (Sigma Aldrich) under different conditions was investigated using decolorization rate as the index. The influence of $\mathrm{pH}$ and temperature on decolorization was studied in presence of $200 \mathrm{mg} . \mathrm{L}^{-1} \mathrm{CR}$ under $\mathrm{pH}$ values ranging from 3 to 10 and temperature ranging from 15 to $45^{\circ} \mathrm{C}$. The agitation effect was studied under different speed shacking conditions $(0,50,100,150$, and $200 \mathrm{rpm}$ ). The influence of initial dye concentration was tested using $100,250,500$, and $1000 \mathrm{mg}$. $\mathrm{L}^{-1}$. In all cultures, $2 \mathrm{~g}$ of fungal fresh biomass was used to inoculate $100 \mathrm{~mL}$ synthetic nutrient broth. Cultures were incubated at $30^{\circ} \mathrm{C}$, for 6 days. The supernatant was used for color reduction measurements and peroxidases activities.

2.3. Biodegradation and Biosorption Treatments. The CR biodegradation treatment was performed with an aqueous solution inoculated with $20 \mathrm{~g} \mathrm{~L}^{-1}$ of fresh fungal biomass. In $250 \mathrm{~mL}$ Erlenmeyer containing $100 \mathrm{~mL}$ of synthetic broth medium was supplemented with $200 \mathrm{mg}$. $\mathrm{L}^{-1} \mathrm{CR}$ dye at $\mathrm{pH} 6.0 \pm 0.2$. After inoculation, cultures were placed in a rotary shaker at $150 \mathrm{rpm}$ and $30^{\circ} \mathrm{C}$ for 10 days. Noninoculated dye solution was designated as negative control. At regular intervals, a sample from the broth medium was collected and centrifuged at $5000 \mathrm{rpm}$ for $15 \mathrm{~min}$ to remove the fungal mycelium. The supernatant was used for $\mathrm{pH}$, color reduction measurements, and enzyme activities assay. The fungal biomass was determined by measuring the dry weight of the pellets suspensions washed twice with distilled water. All cultures were performed in triplicate, and the results are the average.
CR biosorption treatment was conducted with dye aqueous solution in $250 \mathrm{~mL}$ Erlenmeyer containing $100 \mathrm{~mL}$ broth medium and $200 \mathrm{mg}$. $\mathrm{L}^{-1} \mathrm{CR}$ dye inoculated by $2 \mathrm{~g}$ of autoclaved fresh fungal biomass of $A$. niger (inactivated biomass). Flasks were incubated at $30^{\circ} \mathrm{C}$ for $48 \mathrm{~h}$ under stirred conditions $(120 \mathrm{rpm})$. Noninoculated dye solution was designated as negative control.

2.4. Enzymatic Assay. Lignin peroxidase (LiP) activity was determined using veratryl alcohol as a substrate [10]. The assay mixture contained $2 \mathrm{mM}$ veratryl alcohol and $0.4 \mathrm{mM}$ $\mathrm{H}_{2} \mathrm{O}_{2}$ in $50 \mathrm{mM}$ sodium tartrate buffer, $\mathrm{pH} 2.5$. Oxidation of veratryl alcohol was followed by measuring the increase in absorbance at $310 \mathrm{~nm}$ because of the formation of veratraldehyde from $\varepsilon_{310}=9300 \mathrm{M}^{-1} \mathrm{~cm}^{-1}$.

Manganese peroxidase (MnP) activity was determined using $\mathrm{MnSO} 4$ as a substrate [11]. The assay mixture contained $0.5 \mathrm{mM} \mathrm{MnSO} 4$ and $0.5 \mathrm{mM} \mathrm{H}_{2} \mathrm{O}_{2}$ in $50 \mathrm{mM}$ sodium malonate buffer, $\mathrm{pH}$ 4.5. Oxidation of $\mathrm{Mn}^{2+}$ was followed by measuring the increase in absorbance at $270 \mathrm{~nm}$ due to the formation of $\mathrm{Mn}^{3+}$-malonate from $\varepsilon_{270}=11590 \mathrm{M}^{-1} \mathrm{~cm}^{-1}$.

Laccase activity was measured spectrophotometrically with a Genesys 5 spectrophotometer using $1 \mu \mathrm{mol} 2$, 2azino-bis (3-ethylbenzothiazoline-6-sulfonate) (ABTS) as a substrate. One unit of enzyme activity was defined as of ABTS oxidized per minute at $25^{\circ} \mathrm{C}\left(\varepsilon_{420}=29300 \mathrm{M}^{-1} \mathrm{~cm}^{-1}\right)$ [12]. All enzyme activity was expressed as international units (IU).

2.5. UV-Visible and FTIR Analyses. Color reduction was assayed by absorbance measurement at $\lambda_{\max }=495 \mathrm{~nm} \mathrm{~nm}$ using a Jenway 3540 UV/VIS spectrophotometer. After culture centrifugation at $5000 \mathrm{rpm}$ for $15 \mathrm{~min}$, the supernatants were analyzed by measuring the absorbance differences. Decolorization rate was determined according to the following formulation:

$$
\text { Decolorization rate }(\%)=\frac{\left(\mathrm{A}_{0}-\mathrm{A}_{1}\right)}{\mathrm{A}_{0}} \times 100
$$

$A_{0}$ is the dye absorbance before decolorization and $A_{1}$ is the dye absorbance after decolorization.

The decolorization analysis of the biodegraded and crude CR solution was performed by the change in the absorption spectrum in the wavelength range of 200-800 $\mathrm{nm}$ region using a quartz cuvette with an optical path of $5 \mathrm{nn}$.

FTIR analysis of lyophilized fungal biomass was monitored on a Thermo Scientific IR 200 FT-IR spectrophotometer. The FTIR spectra were then recorded between 4000 and $400 \mathrm{~cm}^{-1}$, at a rate of $16 \mathrm{~nm} / \mathrm{s}$.

2.6. LC-MS/MS Analyses of Transformed Metabolites. CR metabolites were analyzed on a LC-MS/MS with an electrospray ionization- (ESI-) interface (Agilent Technologies, USA) equipped with C18 waters column (4.6 mm-250 mm; particle size 5um). Isocratic elution was performed with mobile phase of methanol: water $(90: 10 \mathrm{v} / \mathrm{v})$ at a flow rate of $0.7 \mathrm{~mL} / \mathrm{min}$. 


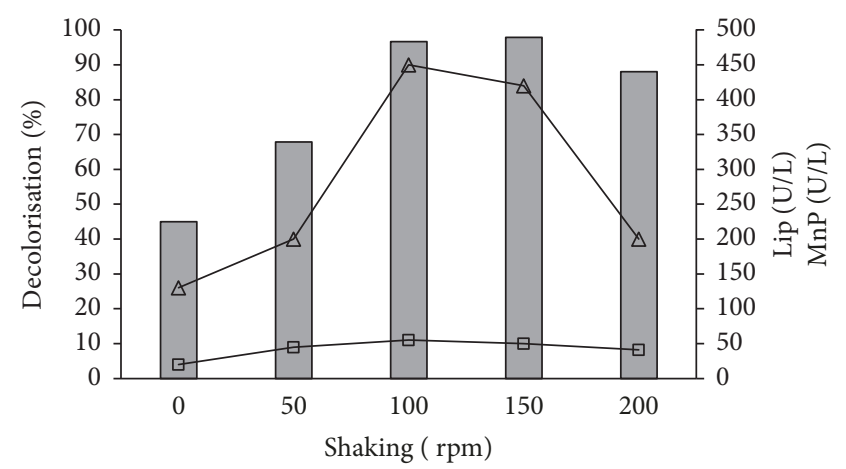

(a)

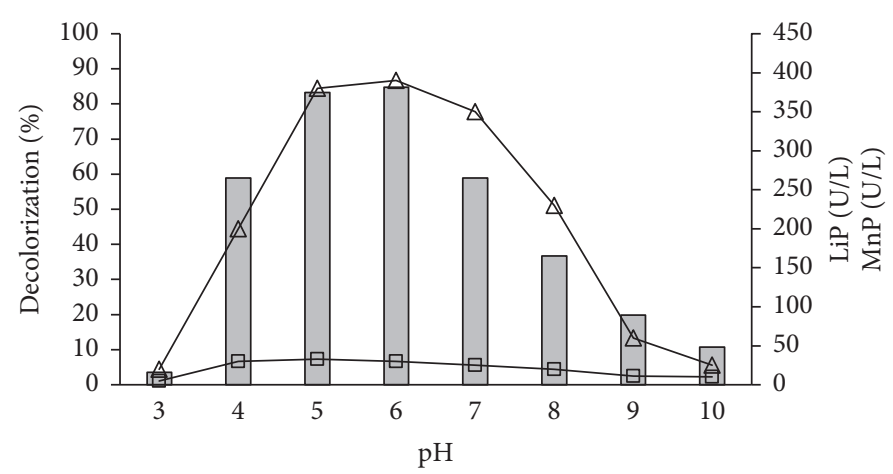

(c)

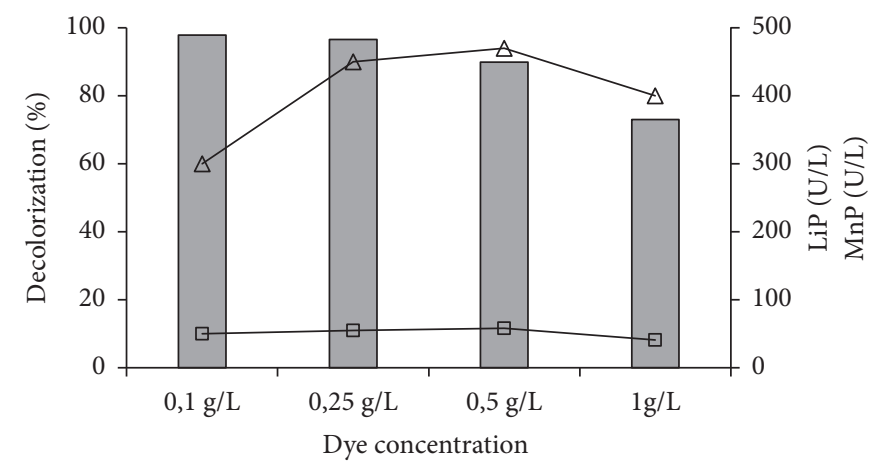

(b)

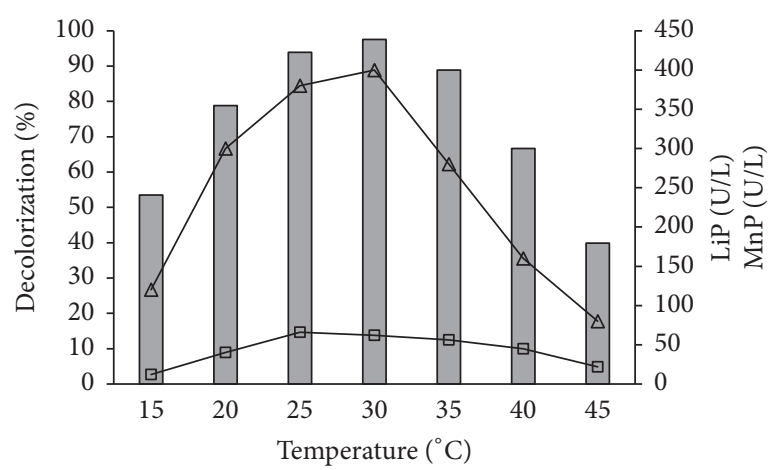

(d)

FIGURE 1: Effect of initial dye shaking (a), dye concentration (b), pH (c), and temperature (d) on CR decolorization efficiency (Gray colored bars), $\operatorname{LiP}(\square)$, and $\mathrm{MnP}$ activities $(\triangle)$.

\subsection{Toxicity Assay}

2.7.1. Phytotoxicity Assay. The phytotoxicity assays were performed to assess the toxicity of dye before and after degradation. The experiment was conducted using Zea mais and Solanum lycopersicum seeds. 10 seeds were wetted $(3 \mathrm{~mL}$ per day) with dye solution $\left(200 \mathrm{mg} . \mathrm{L}^{-1}\right)$ or treated CR solution in separated Petri dishes. The control groups were treated with distilled water. All samples were incubated at the same environmental conditions and repeated three times. Percent of germination and length of shoot and root were recorded after 7 days.

2.7.2. Microtoxicity Assay. Bacillus cereus ATCC 11778 and Escherichia coli ATCC 10536 strains were used for toxicity evaluation of the untreated and treated RC solution by Aspergillus niger. The two strains growths were studied on nutrient broth (NB) medium as control and on NB medium supplemented with $200 \mathrm{mg} \mathrm{L}^{-1}$ of CR before and after biodegradation. Incubation temperature was $30^{\circ} \mathrm{C}$ and $37^{\circ} \mathrm{C}$ for B. cereus and E. coli, respectively. The bacterial growth was assessed by OD at $600 \mathrm{~nm}$ recorded at $1 \mathrm{~h}$ interval during $8 \mathrm{~h}$ [13].

2.8. Statistical Analysis. An analysis of variance (a one-way ANOVA) was conducted by employing performed (SPSS) version 16.0 software. SAS 9.0 software was used for all statistical analysis with multiple comparison tests. Effects were considered significant when the $\mathrm{P}$ value was $<0.05$.

\section{Results and Discussion}

3.1. Process Parameters' Optimization for Congo Red Decolorization by $A$. niger. CR decolorization efficiency and enzyme production ( $\mathrm{LiP}$ and $\mathrm{MnP}$ ) by $A$. niger were investigated by different process parameters. Effects of speed shaking, $\mathrm{pH}$, temperature, and initial dye concentration are shown in Figure 1. The effect of shaking speed was found to be highly significant $(p<0.01)$ on CR decolorization. When the speed increases from 0 to $150 \mathrm{rpm}$, the decolorization efficiency increases from $45 \%$ to $98 \%$ after six days of culture, indicating that shaking increases the mixing of the oxygen present in the medium, thus helping Aspergillus niger growth (Figure 1(a)). The same results were obtained by Kumar et al. [14], who found that shaking was beneficial for achieving maximum dye decolorization of brilliant green by Aspergillus sp. as a result of better oxygen transfer and nutrient distribution through the medium. However, a decline was observed beyond a speed of 150 rpm, which can be explained by pellet formation decrease in spite of the high biomass produced. The maximum LiP and $\mathrm{MnP}$ activities were obtained at a speed of $100 \mathrm{rpm}$ (54 and 452 U.L ${ }^{-1}$, respectively). The differences between enzymatic activities recorded between 100 and $150 \mathrm{rpm}$ are not significant $(\mathrm{P}>0.05)$. When the speed increased from 


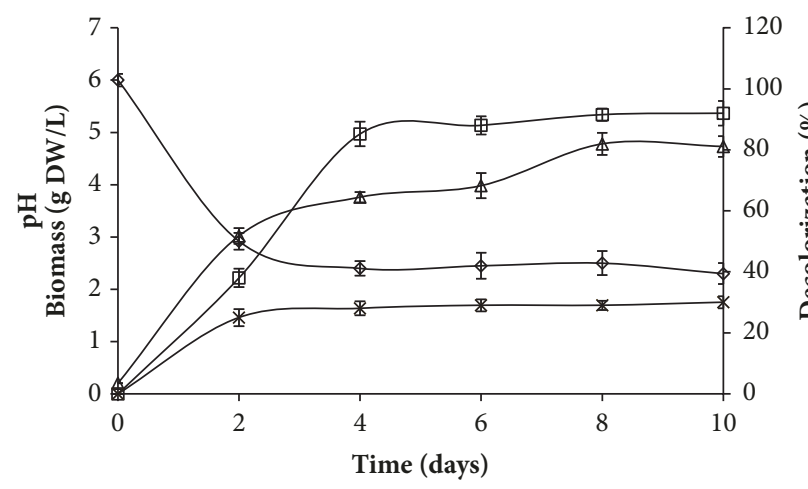

(a)

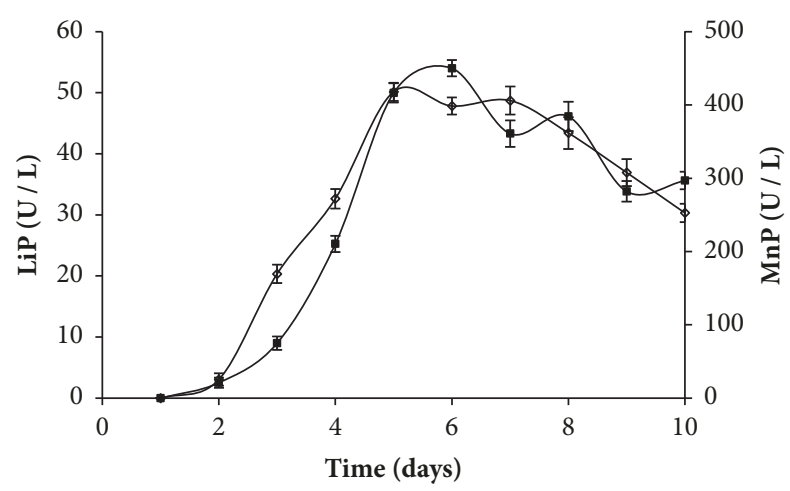

(b)

Figure 2: Time course of $\mathrm{pH}(\diamond)$, Biomass $(\triangle)$, and decolorization ( $\square$ : with activated A. niger, x: with inactivated $A$. niger) (a); LiP $(\mathbf{\Delta})$ and $\mathrm{MnP}(\boldsymbol{\square})$ (b) during azo dye CR treatment by $A$. niger. The error bars represent the standard deviation of measurements for 3 samples.

150 to $200 \mathrm{rpm}$, the MnP activity decreased but LiP activity remained almost constant. Mahmoud et al. [15] reported an increase in the decolorization rate of direct red azo dye by $A$. niger with increasing the agitation speed. The maximum removal efficiency was recorded at agitation speed of $250 \mathrm{rpm}$, after which no significant increase was noticed. On the contrary, some authors noticed decolorization decreased under shaking condition due to the competition between azo dyes and oxygen for reduced electron carriers [16].

CR decolorization is also affected by medium $\mathrm{pH}$. A. niger showed high CR removal (85\%) and enzyme activities under slightly acidic $\mathrm{pH}$ varying from 5 to 6 (differences are not significant $\mathrm{P}>0.05$ ) (Figure $1(\mathrm{~b})$ ). In fact, $\mathrm{MnP}$ activity notably dropped at high $\mathrm{pH}$ values $(\mathrm{pH}>7)$, which can be due to enzymes stability. This enzyme may be stable only at acidic pH. Michaels and Lewis 1986 showed that medium $\mathrm{pH}$ is one of the critical environmental factors that affects azo biodegradation. Kumar et al. 2011 obtained methyl violet biodegradation by Aspergillus sp. only in slightly acidic conditions ( $\mathrm{pH}$ 5.5) and that the decolorization was inhibited at a $\mathrm{pH}$ higher than 6.5 .

From Figure 1(c), it can be deduced that a temperature around $30^{\circ} \mathrm{C}$ is the most favorable temperature to carry out this decolorization and a significant decrease was observed at higher temperature. This can be explained by cell viability reduction at high temperature or to the inactivation of the enzymes responsible for RC decolorization. Parshetti et al. [17] showed that optimum temperature for dye decolorization for most fungi varied between 25 and $35^{\circ} \mathrm{C}$.

Figure $1(\mathrm{~d})$ shows that $\mathrm{CR}$ removal was slightly inhibited at $0.5 \mathrm{gL}-1$, and the best result was found with $0.25 \mathrm{~g} . \mathrm{L}^{-1}$ with a decolorization rate of $96 \%$ and enzyme production of 56 and $470 \mathrm{U}^{-1} \mathrm{~L}^{-1}$ for $\mathrm{LiP}$ and MnP, respectively. When the initial dye concentration increased to 1g.L-1, a significant reduction in the decolorization rate was observed $(73 \%)$, which can be due to the dye toxicity at high concentrations [18]. Same result was reported by Parshetti et al. [17], who showed that reactive blue- 25 at high concentration affected the decolorization performance of Aspergillus ochraceus.

3.2. Time Effect on CR Decolorization and Enzymatic Activities. Optimal conditions previously set up were used to study the biodegradation and the adsorption ability of $A$. niger. RC removal and enzymatic activities were conducted with $2 \mathrm{~g}$ of fresh activated or inactivated mycelia, inoculated into 100 $\mathrm{mL}$ of synthetic media containing $250 \mathrm{mg}$. L-1 of CR dye, and incubated at $30^{\circ} \mathrm{C}$. Decolorization, biomass production, $\mathrm{pH}$, LiP, and $\mathrm{MnP}$ activities were monitored during 6 days (Figure 2).

The biomass increased and $\mathrm{pH}$ decreased the first six days and then stabilized. The maximum mycelium dry weight obtained was 6.4 g. $\mathrm{L}^{-1}$. A. niger growth induced a significant decolorization that reached $97 \%$ after 6 days of incubation. However, inactivated cells led to $27 \%$ color removal during the same period (Figure 2(a)). Then, the decolorization could be attributed to both biodegradation and dye adsorption on the fungal mycelium. Therefore, $97 \%$ of decolorization is the result of two-process combination, the enzymatic activity responsible for the molecule degradation and adsorption phenomena. In fact, $1 \mathrm{~g}$ of fresh biomass can eliminate $27 \%$ of CR dye by adsorption mechanism and $70 \%$ by enzymatic biodegradation.

Time course for LiP and MnP produced by A. niger was achieved in order to evaluate the maximum enzyme activity during CR removal by $A$. niger (Figure 2(b)). LiP activity was detected after 2 days and reached a maximum at the 5 th of the culture. However, maximum MnP activity was obtained in the 6th day. The highest MnP and LiP activities were 53.2 \pm 1.41 UI.L $^{-1}$ and $450.13 \pm 11$ UI.L $^{-1}$, respectively. However, laccase activity was not detected. Since the MnP activity level produced was much higher than the LiP activity, MnP seemed to play the most important role in the decolorization. The presence of ligninolytic extracellular enzymes in culture supports biological decolorization alongside the nonbiological color removal by adsorption [19]. Several studies have shown that ligninolytic fungal enzymes are efficient for dye decolorization [20, 21]. Parshetti et al. [17] have shown 


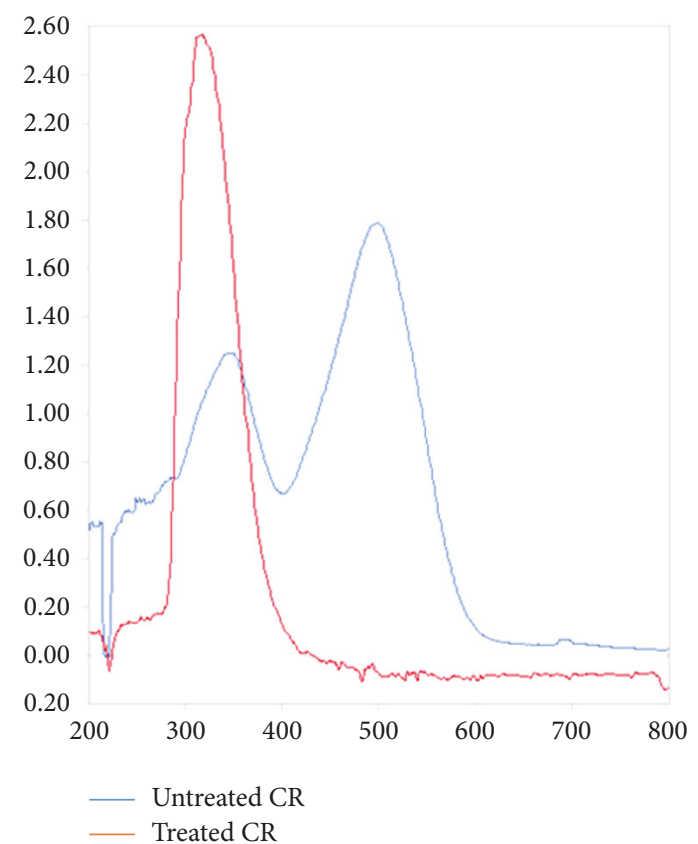

FIGURE 3: Changes in UV-visible absorption spectrum of CR (200 mg.L-1) before and after CR decolorization by A. niger treatment at shaking condition $\left(200 \mathrm{mg}\right.$. $\mathrm{L}^{-1} \mathrm{CR}$ dye at $\mathrm{pH} 6.0 \pm 0.2$ shaked at 150 rpm incubated at $30^{\circ} \mathrm{C}$ for 8 days).

the presence of lignin peroxidase, laccase, and tyrosinase produced by Aspergillus ochraceus during reactive blue 25 decolorization.

3.3. CR Color Removal By A. niger. CR color removal was confirmed by UV-visible analysis (200-800 nm) (Figure 3). CR UV-Vis scanning showed two peaks. One extended at $340 \mathrm{~nm}$, which is due to the interaction between aromatic hydrocarbon or polycyclic aromatic hydrocarbon groups and other chromophore and another at $495 \mathrm{~nm}$, which had a relation to azo double bond and large conjugated system for the whole dye molecule. After $96 \mathrm{~h}$ treatment, a decrease in the major peak intensity at $495 \mathrm{~nm}$ was observed. It indicated that dye structure especially that of chromophore was transformed during A. niger treatment. However, the absorbance at $340 \mathrm{~nm}$ was increased which evinced that interaction of the aromatic hydrocarbons or polycyclic aromatic hydrocarbon groups and some chromophore were partly destroyed, or new aromatic compounds might appear [22]. These changes suggested that $A$. niger is able to transform the CR dye to other compounds. This result suggested the chromophore group's breakdown. Wang et al. [23] reported that the degradation of the aromatic hydrocarbon or polycyclic aromatic hydrocarbon groups completely seemed to be more difficult than the destruction of the azo double bond and the large conjugated system.

3.4. CR Adsorption on A. niger Biomass. In order to elucidate the nature of the functional groups responsible for the biosorption, FTIR analysis of the lyophilized biomass was carried out before and after incubation in CR solution (200 mg.L-1) (Figures 4(a) and 4(b)). The FTIR spectra of A. niger biomass before treatment showed the characteristic band at $3275 \mathrm{~cm}-1$, which is attributed to $\mathrm{O}-\mathrm{H}$ bending vibrations. The peak at $2937 \mathrm{~cm}-1$ corresponds to asymmetric and symmetric stretching of the $\mathrm{C}-\mathrm{H}$ bond of $-\mathrm{CH} 2$ group. The band at $1641 \mathrm{~cm}-1$ is due to the bending of $\mathrm{N}-\mathrm{H}$ groups of chitin on the cell wall structure of fungal pellets [9]. The peaks around $1559 \mathrm{~cm}-1$ indicated the presence of amide which resulted from $\mathrm{NH}$ deformation. The bands at $1420 \mathrm{~cm}-1$, $1139 \mathrm{~cm}-1$, and $1090 \mathrm{~cm}-1$ are representing $-\mathrm{CH} 3$ wagging (umbrella deformation), symmetric -SO3 stretching, and $\mathrm{C}-\mathrm{OH}$ stretching vibrations, respectively, which were due to several functional groups present on the fungal cell walls [22]. The peak at $579 \mathrm{~cm}-1$ is corresponding to $\mathrm{C}-\mathrm{O}$ bending vibrations. The adsorption of $\mathrm{CR}$ on the fungal biomass induced an increase in some peaks intensity, in particular, those around 3287, 2933, 1649, 1154, and $1034 \mathrm{~cm}-1$. An appearance of new peaks at 2859,1379, 1262, and $1154 \mathrm{~cm}-1$ was due to introduction of new functionalities on the surface of biosorbent which confirmed the CR adsorption on fungal biomass. Similar FTIR results were observed for the phenolic compounds' biosorption on various fungus biomass [23].

3.5. Bioconversion of CR by A. niger. LC-MS/MS spectra of both treated and nontreated CR dye solution display different patterns the major several compounds obtained after CR decomposition at different $\mathrm{m} / \mathrm{z}$ ratios confirming the CR biodegradation by A. niger (Figure 5). According to LC-MS/ MS spectrum, the possible degradation pathway for CR dye is showed in Figure 6. The degradation of the CR dye may occur via the following steps: (i) the simultaneous total deamination and oxygenation of (CR) forming the compound (A) with $\mathrm{m} / \mathrm{z}$ value of 698 . When the total deamination is followed by the loss of both sodium atoms, the degraded products (B) and (C) with $\mathrm{m} / \mathrm{z}$ values of 663 and 619 , respectively, are formed. (ii) The partial deamination of (CR) and the peroxidase asymmetric cleavage of $\mathrm{C}-\mathrm{N}$ bond between the aromatic ring and the azo group with the loss of a sodium atom afford the intermediates (H) and (D) with $\mathrm{m} / \mathrm{z}$ values of 227 and 429, respectively. (iii) The peroxidase asymmetric cleavage of $\mathrm{C}-\mathrm{N}$ bond followed by deprotonation leaded to the intermediate $(G)$ with $\mathrm{m} / \mathrm{z}$ value of 271 . (iv) The benzene ring opening and dehydrogenation formed intermediates (E) and (F) with $\mathrm{m} / \mathrm{z}$ values of 371 and 321 , respectively. (v) The peroxidase cleavage produces also low molecular weight of stable degraded products, the sodium naphthalene sulfonate (I) $(\mathrm{m} / \mathrm{z}=227)$ and the cycloheptadienylium (J) $(\mathrm{m} / \mathrm{z}=91)$. In addition to LiP and $\mathrm{MnP}$ as degrading agents, Figures 5 and 6 showed that the most abundant intermediates of degradation (A, B, C, H, and D) resulted from deamination of the CR dye. This is in agreement with the literature which reported the GlcN6P desaminase role of $A$. niger [24].

3.6. Phytotoxicity Analysis. Phytotoxicity analysis revealed the toxicity of CR and its products to Zea mais and Solanum lycopersicum seeds (Table 1). Compared to water treatment, CR before degradation reduced significantly the germination rate, shoot, and root length of both Zea mais and Solanum 


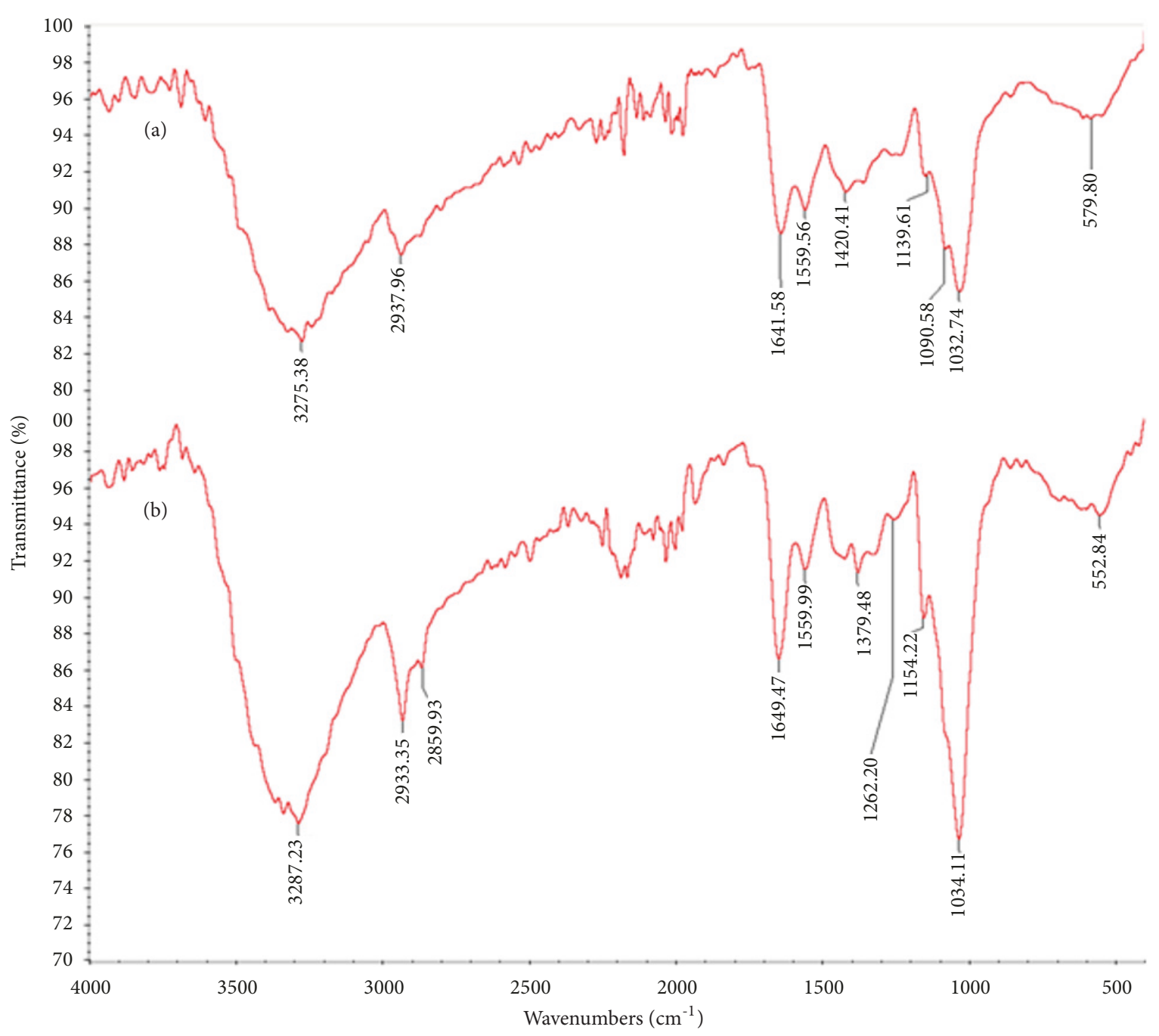

FIGURE 4: FTIR spectra of inactive A. niger before (a) and after biosorption of CR dye (b) $\left(100 \mathrm{~mL}\right.$ broth medium and $200 \mathrm{mg}$. $\mathrm{L}^{-1}$ CR dye inoculated by $2 \mathrm{~g}$ of autoclaved fresh fungal biomass of $A$. niger (inactivated biomass) incubated at $30^{\circ} \mathrm{C}$ for $48 \mathrm{~h}$ under stirred conditions ( 120 $\mathrm{rpm})$ ).

TABLE 1: Phytotoxicity study of CR before and after biodegradation by A. niger on Zea mais and Solanum lycopersicum.

\begin{tabular}{|c|c|c|c|c|c|c|}
\hline \multirow{2}{*}{ Parameters } & \multicolumn{3}{|c|}{ Zea mais } & \multicolumn{3}{|c|}{ Solanum lycopersicum } \\
\hline & Water & Congo red & $\begin{array}{c}\text { Transformation } \\
\text { intermediates }\end{array}$ & Water & Congo red & $\begin{array}{c}\text { Transformation } \\
\text { intermediates }\end{array}$ \\
\hline $\begin{array}{l}\text { Germination } \\
(\%)\end{array}$ & $91 \pm 2.02$ & $\begin{array}{c}60 \pm 3.52 \\
(*)\end{array}$ & $\begin{array}{c}82 \pm 3.05 \\
(\mathrm{Ns})\end{array}$ & $88 \pm 2.08$ & $\begin{array}{c}60 \pm 3.78 \\
(*)\end{array}$ & $\begin{array}{c}81 \pm 2.72 \\
(\mathrm{Ns})\end{array}$ \\
\hline $\begin{array}{l}\text { Shoot length } \\
(\mathrm{cm})\end{array}$ & $12.2 \pm 1.02$ & $\begin{array}{c}6.5 \pm 0.36 \\
(*)\end{array}$ & $\begin{array}{c}10.9 \pm 0.52 \\
\text { (Ns) }\end{array}$ & $5.16 \pm 0.44$ & $\begin{array}{c}1.8 \pm 0.15 \\
(* *)\end{array}$ & $\begin{array}{l}4.66 \pm 0.44 \\
(\mathrm{Ns})\end{array}$ \\
\hline $\begin{array}{l}\text { Root length } \\
(\mathrm{cm})\end{array}$ & $4.26 \pm 0.37$ & $\begin{array}{c}1.7 \pm 0.14 \\
(* *)\end{array}$ & $\begin{array}{c}3.16 \pm 0.21 \\
(\mathrm{Ns})\end{array}$ & $3.13 \pm 0.12$ & $\begin{array}{c}2.06 \pm 0.17 \\
(*)\end{array}$ & $\begin{array}{c}3.2 \pm 0.15 \\
(\mathrm{Ns})\end{array}$ \\
\hline
\end{tabular}

Ns: differences are not significant; $*$ : differences are significant at $\mathrm{P} \leq 0.05, * *$ : differences are significant at $\mathrm{P} \leq 0.01$ according to ANOVA statistical analysis.

lycopersicum $(\mathrm{p}<0.01)$. Nevertheless, the metabolites generated after the CR biodegradation are less toxic than the crude dye. In fact, there is no difference between the shoot and root length of both Zea mais and Solanum lycopersicum treated with treated CR and with water (differences were not significant with $\mathrm{P}>0.05)$. Babu et al. [5] showed that the degradation metabolites of $\mathrm{CR}$ are comparatively less toxic than the crude CR to Artemia franciscana. Therefore, in addition to its degradation, the CR dye is detoxified by $A$. niger indicating the degradation of the amines in the solution. This result is in accordance with the deaminating effect of GlcN6P deaminase in A. niger observed in LC-MS/MS data. 


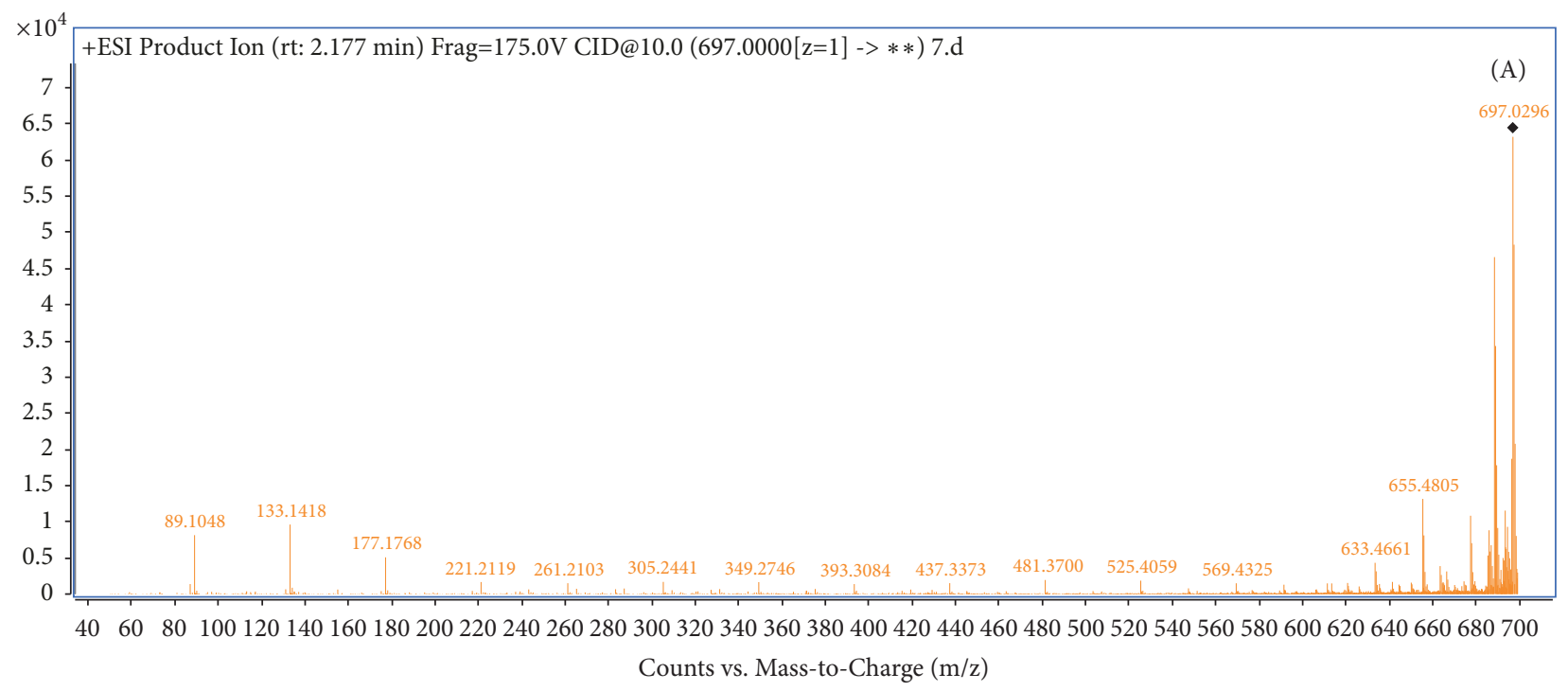

(a)

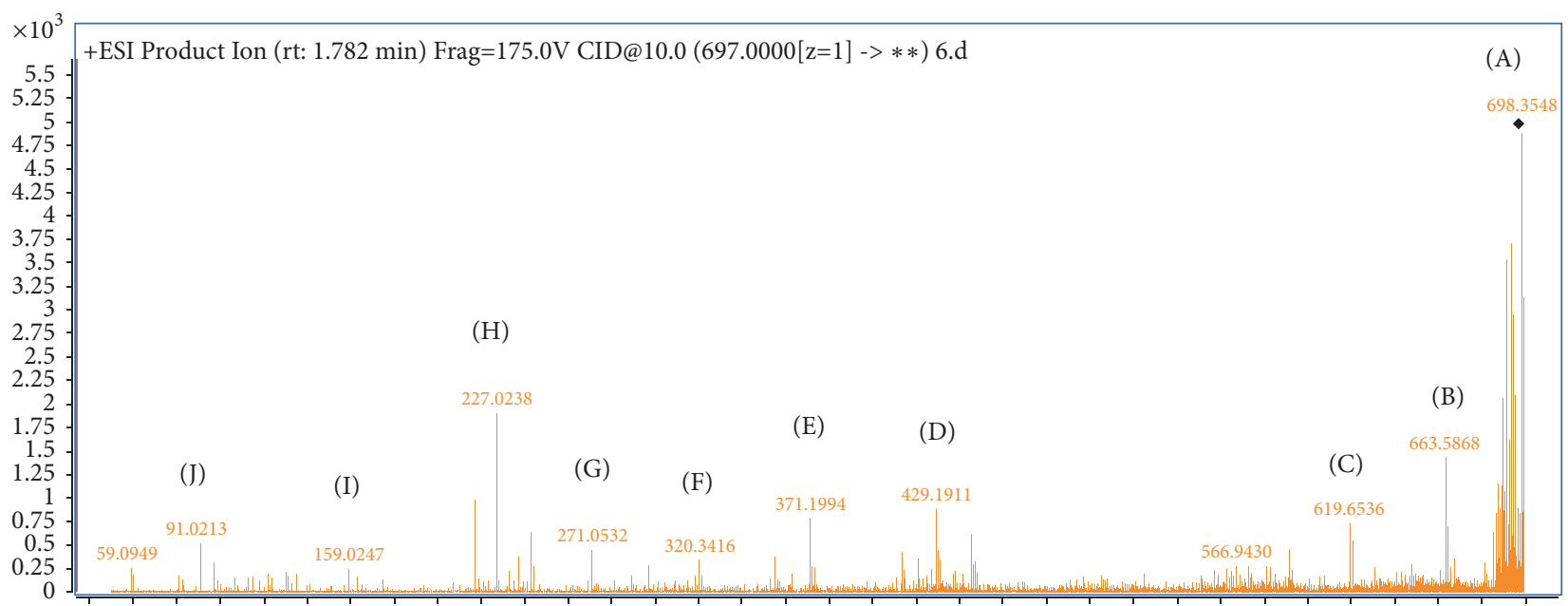

406080100120140160180200220240260280300320340360380400420440460480500520540560580600620640660680700

Counts vs. Mass-to-Charge $(\mathrm{m} / \mathrm{z})$

(b)

FIGURE 5: LC-MS/MS spectrum of crude CR (a) and degraded product formed during the CR decolorization process by A. niger (b) (200 mg. $\mathrm{L}^{-1} \mathrm{CR}$ dye at $\mathrm{pH} 6.0 \pm 0.2$ shaked at $150 \mathrm{rpm}$ incubated at $30^{\circ} \mathrm{C}$ for 8 days).

3.7. Microtoxicity Analysis. Microbial toxicity of crude CR solution (200 mg.L-1) and treated one was tested against B. cereus ATCC 11778 and E. coli ATCC 10536 (Figure 7). Inhibition was obtained with untreated CR dye solution. In fact, after 8 hours of incubation $B$. cereus and $E$. coli density remained very lower in the media containing crude CR than the control ones, with a significant difference $(\mathrm{p}<0.05)$, while an improvement of bacterial growth was observed in the media containing treated dye. Density values of $B$. cereus and $E$. coli were 1.34 and 1.68, respectively, on treated CR and 2.019 and 2.37, respectively, on nutrient broth. Therefore, the CR degradation seems to detoxify the azo dye.

\section{Conclusion}

This study revealed that the CR was successfully decolored and biodegraded by Aspergillus niger. High decolorization efficiency (97\%) was obtained after six days of culture. $1 \mathrm{~g}$ of fresh biomass can eliminate $27 \%$ of CR dye by adsorption mechanism and $70 \%$ by enzymatic biodegradation. This degradation is due to the combined action of three enzymes LiP, MnP, and probably deaminase. UV-Vis, FTIR, and LCMS/MS analysis as well as phytotoxicity and microtoxicity tests have proven the effective role of degrading and detoxifying $\mathrm{CR}$ dye by $A$. niger. This biological process is recommendable for further development as a potential technology for wastewater treatment. 


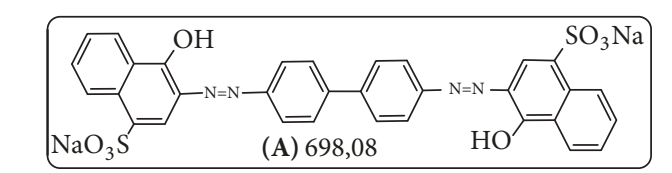

sodium $3,3^{\prime}-\left(\left[1,1^{\prime}\right.\right.$-biphenyl $]-4,4^{\prime}$-diylbis(diazene-2,1-
diyl $)$ )bis(4-hydroxynaphthalene-1-sulfonate)

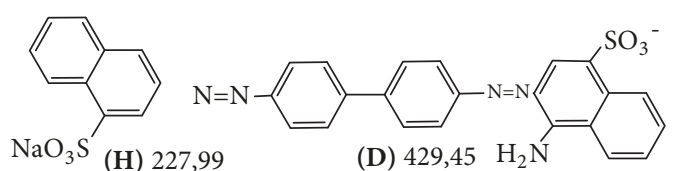

sodium naphthalene-1-sulfonate

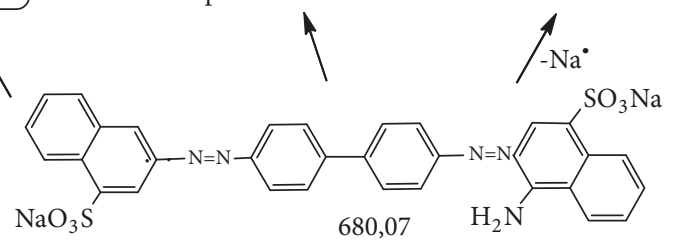

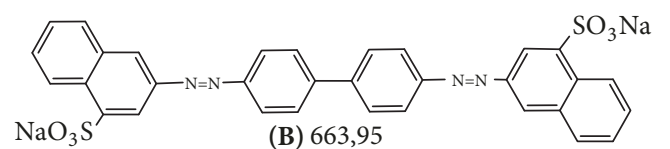

sodium 3,3' -([1,1' -biphenyl]-4, $4^{\prime}$-diylbis(diazene-2,1diyl))bis(naphthalene-1-sulfonate)

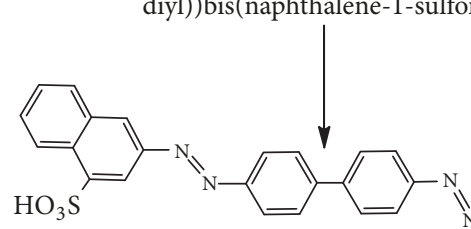

(C) 619,07

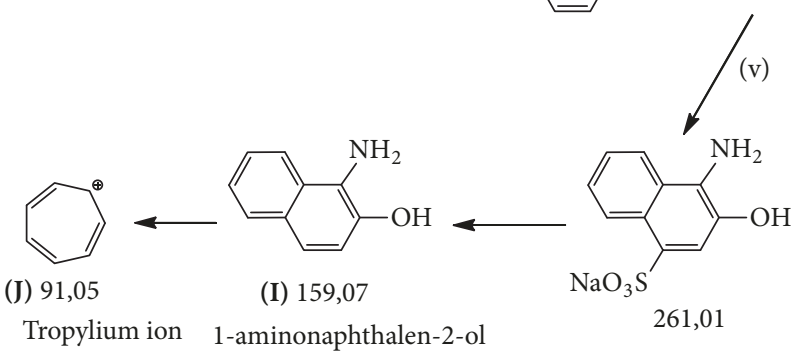

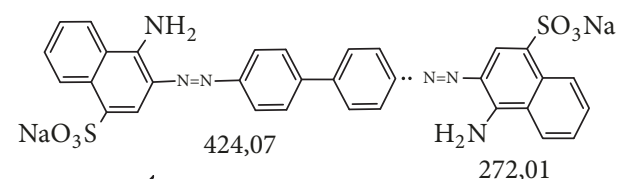

(ii)
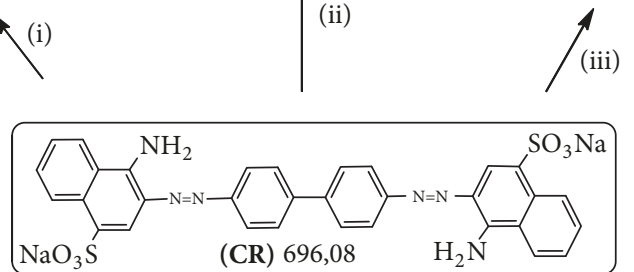

(iv)

$\mathrm{NaO}_{3} \mathrm{~S}$

(G) 271.01

sodium $1 H$-naphtho[1,2-d] $[1,2,3]$ triazole-5-sulfonate

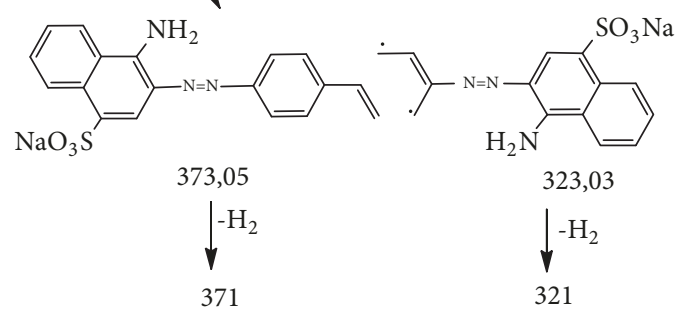

(E)

(F)

Figure 6: Proposed biodegradation pathway of CR using A. niger, with the identification of different degradation intermediates by LCMS/MS.

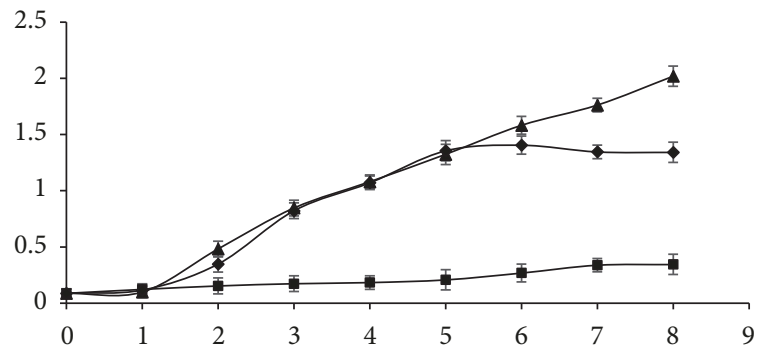

(a)

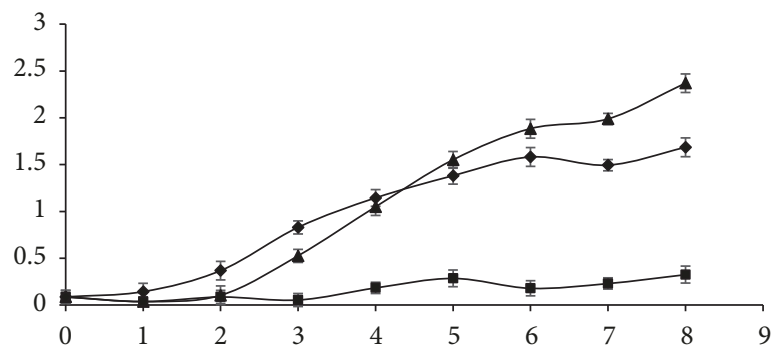

(b)

FIGURE 7: Kinetics growth of Bacillus cereus ATCC 11778 (a) and Escherichia coli ATCC 10536 (b) on nutrient broth, CR (200 mg.L $\left.\mathrm{L}^{-1}\right)$, and its transformation metabolites. The error bars represent the standard deviation of measurements for 3 samples.

\section{Data Availability}

The data used to support the findings of this study are available from the corresponding author upon request.

\section{Conflicts of Interest}

The authors declare that there are no conflicts of interest regarding the publication of this paper. 


\section{Acknowledgments}

The authors wish to acknowledge the Ministry of Higher Education and Scientific Research in Tunisia, which has facilitated the work carried out.

\section{References}

[1] S. L. Postel, G. C. Daily, and P. R. Ehrlich, "Human appropriation of renewable fresh water," Science, vol. 271, no. 5250, pp. 785-788, 1996.

[2] X. Liu, W. Li, N. Chen, X. Xing, C. Dong, and Y. Wang, "Ag-ZnO heterostructure nanoparticles with plasmon-enhanced catalytic degradation for Congo red under visible light," RSC Advances, vol. 5, no. 43, pp. 34456-34465, 2015.

[3] N. Daneshvar, D. Salari, and A. R. Khataee, "Photocatalytic degradation of azo dye acid red 14 in water on $\mathrm{ZnO}$ as an alternative catalyst to $\mathrm{TiO}_{2}$," Journal of Photochemistry and Photobiology A: Chemistry, vol. 162, no. 2-3, pp. 317-322, 2004.

[4] M. Sarioglu, U. Bali, and T. Bisgin, "The removal of C.I. Basic Red 46 in a mixed methanogenic anaerobic culture," Dyes and Pigments, vol. 74, no. 1, pp. 223-229, 2007.

[5] S. Satheesh Babu, C. Mohandass, A. S. Vijayaraj, and M. A. Dhale, "Detoxification and color removal of Congo red by a novel Dietzia sp. (DTS26)- A microcosm approach," Ecotoxicology and Environmental Safety, vol. 114, pp. 52-60, 2015.

[6] D. T. D’Souza, R. Tiwari, A. K. Sah, and C. Raghukumar, "Enhanced production of laccase by a marine fungus during treatment of colored effluents and synthetic dyes," Enzyme and Microbial Technology, vol. 38, no. 3-4, pp. 504-511, 2006.

[7] E. J. R. Almeida and C. R. Corso, "Comparative study of toxicity of azo dye Procion Red MX-5B following biosorption and biodegradation treatments with the fungi Aspergillus niger and Aspergillus terreus," Chemosphere, vol. 112, pp. 317-322, 2014.

[8] M. Chhabra, S. Mishra, and T. R. Sreekrishnan, "Laccase/mediator assisted degradation of triarylmethane dyes in a continuous membrane reactor," Journal of Biotechnology, vol. 143, no. 1, pp. 69-78, 2009.

[9] L. Ayed, N. Chammam, N. Asses, and M. Hamdi, "Optimization of Biological Pretreatment of Green Table Olive Processing Wastewaters Using Aspergillus niger," Journal of Bioremediation \& Biodegradation, vol. 5, p. 212, 2013.

[10] M. Tien and T. K. Kirk, "Lignin-degrading enzyme from Phanerochaete chrysosporium: Purification, characterization, and catalytic properties of a unique $\mathrm{H}_{2} \mathrm{O}_{2}$-requiring oxygenase," Proceedings of the National Acadamy of Sciences of the United States of America, vol. 81, no. 8, pp. 2280-2284, 1984.

[11] P. Giardina, G. Palmieri, B. Fontanella, V. Rivieccio, and G. Sannia, "Manganese peroxidase isoenzymes produced by Pleurotus ostreatus grown on wood sawdust," Archives of Biochemistry and Biophysics, vol. 376, no. 1, pp. 171-179, 2000.

[12] B. S. Wolfenden and R. L. Willson, "Radical-cations as reference chromogens in kinetic studies of one-electron transfer reactions: Pulse radiolysis studies of 2,21-azinobis-(3ethylbenzthiazoline-6-sulphonate)," Journal of the Chemical Society, Perkin Transactions 2, no. 7, pp. 805-812, 1982.

[13] R. Capasso, A. Evidente, L. Schivo, G. Orru, M. A. Marcialis, and G. Cristinzio, "Antibacterial polyphenols from olive oil mill waste waters," Journal of Applied Bacteriology, vol. 79, no. 4, pp. 393-398, 1995.

[14] C. G. Kumar, P. Mongolla, A. Basha, J. Joseph, V. U. M. Sarma, and A. Kamal, "Decolorization and Biotransformation of Triphenylmethane Dye, Methyl Violet, by Aspergillus sp. Isolated from Ladakh, India," Journal of Microbiology and Biotechnology, vol. 21, no. 3, pp. 267-273, 2011.

[15] M. S. Mahmoud, M. K. Mostafa, S. A. Mohamed, N. A. Sobhy, and M. Nasr, "Bioremediation of red azo dye from aqueous solutions by Aspergillus niger strain isolated from textile wastewater," Journal of Environmental Chemical Engineering (JECE), vol. 5, no. 1, 2017.

[16] S. D. Kalme, G. K. Parshetti, S. U. Jadhav, and S. P. Govindwar, "Biodegradation of benzidine based dye Direct Blue- 6 by Pseudomonas desmolyticum NCIM 2112," Bioresource Technology, vol. 98, no. 7, pp. 1405-1410, 2007.

[17] G. K. Parshetti, S. D. Kalme, S. S. Gomare, and S. P. Govindwar, "Biodegradation of Reactive blue-25 by Aspergillus ochraceus NCIM-1146," Bioresource Technology, vol. 98, no. 18, pp. 3638$3642,2007$.

[18] B.-E. Wang and Y.-Y. Hu, "Bioaccumulation versus adsorption of reactive dye by immobilized growing Aspergillus fumigatus beads," Journal of Hazardous Materials, vol. 157, no. 1, pp. 1-7, 2008.

[19] Y. Wang and J. Yu, "Adsorption and degreadation of synthetic dyes on the mycelium of Trametes versicolor," Water Science and Technology, vol. 38, no. 4-5, pp. 233-238, 1998.

[20] G. McMullan, C. Meehan, A. Conneely et al., "Microbial decolourisation and degradation of textile dyes," Applied Microbiology and Biotechnology, vol. 56, no. 1-2, pp. 81-87, 2001.

[21] D. Wesenberg, I. Kyriakides, and S. N. Agathos, "White-rot fungi and their enzymes for the treatment of industrial dye effluents," Biotechnology Advances, vol. 22, no. 1-2, pp. 161-187, 2003.

[22] Y. B. Chen, X. X. Wang, X. Z. Fu, and Y. L. Li, "Photocatalytic degradation process of azo dye congo red in aqueous solution," Journal of Catalysis, vol. 26, no. 1, pp. 37-42, 2005.

[23] N. Wang, Y. Chu, F. Wu, Z. Zhao, and X. Xu, "Decolorization and degradation of Congo red by a newly isolated white rot fungus, Ceriporia lacerata, from decayed mulberry branches," International Biodeterioration \& Biodegradation, vol. 117, pp. 236-244, 2017.

[24] E. Guibal, C. Roulph, and P. Le Cloirec, "Infrared Spectroscopic Study of Uranyl Biosorption by Fungal Biomass and Materials of Biological Origin," Environmental Science \& Technology, vol. 29, no. 10, pp. 2496-2503, 1995. 


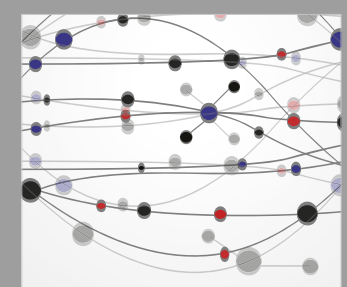

The Scientific World Journal
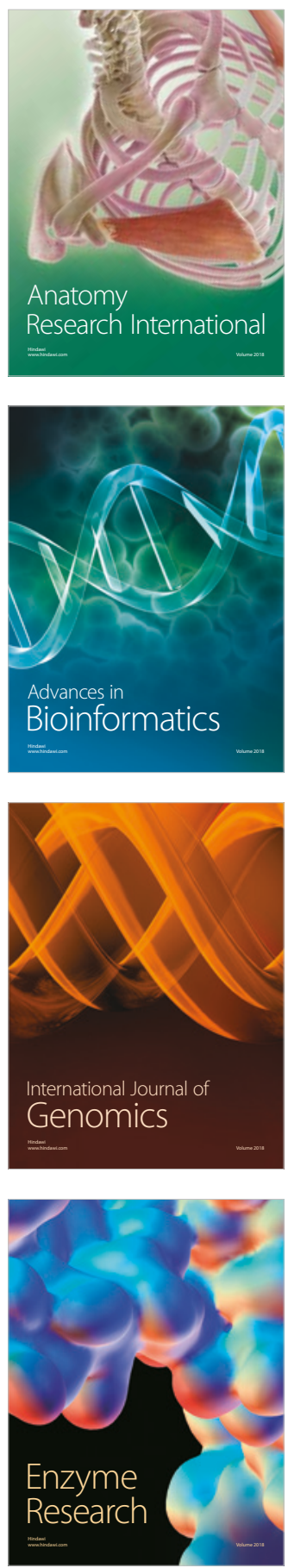
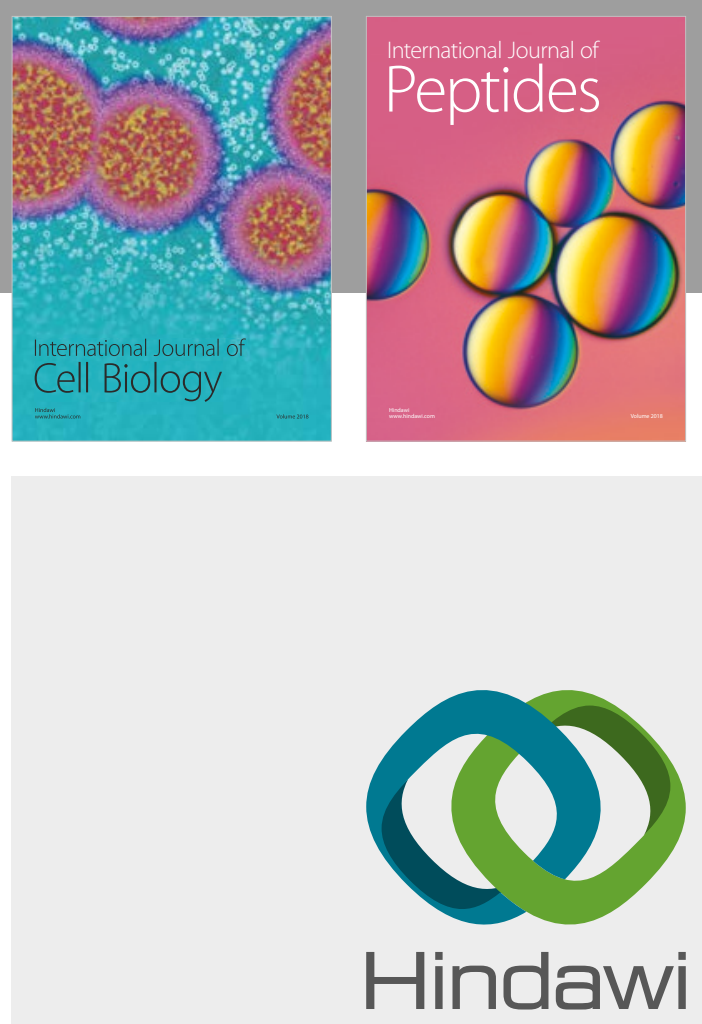

Submit your manuscripts at

www.hindawi.com
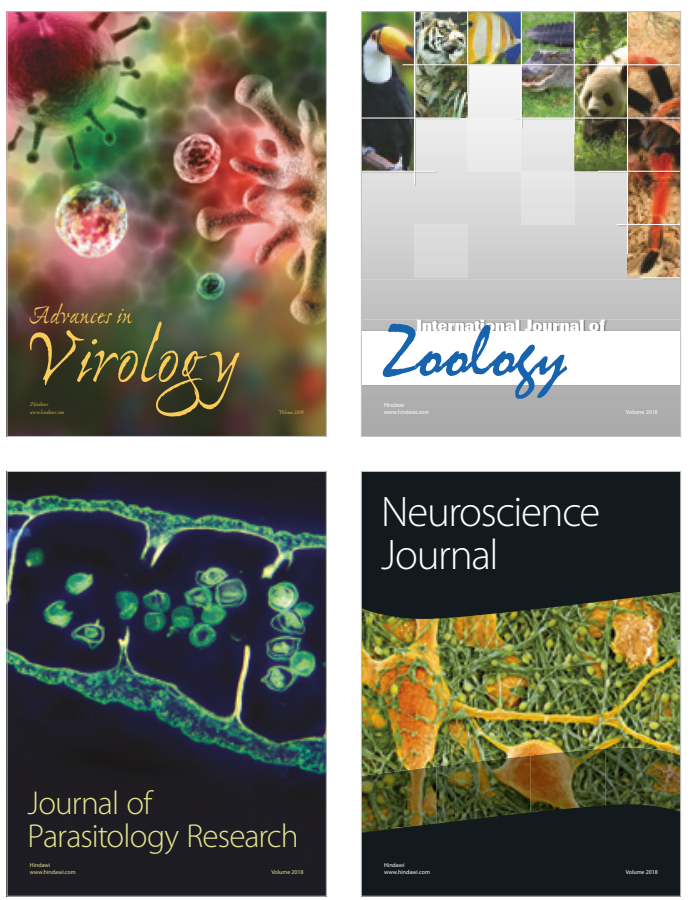
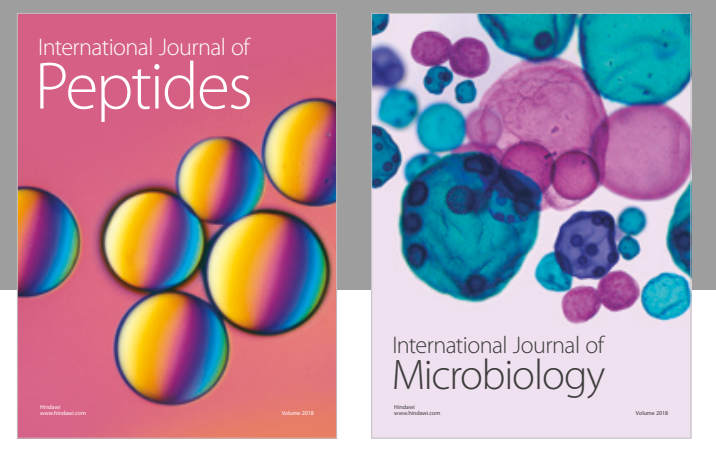

nternational Journal of Microbiology
Journal of
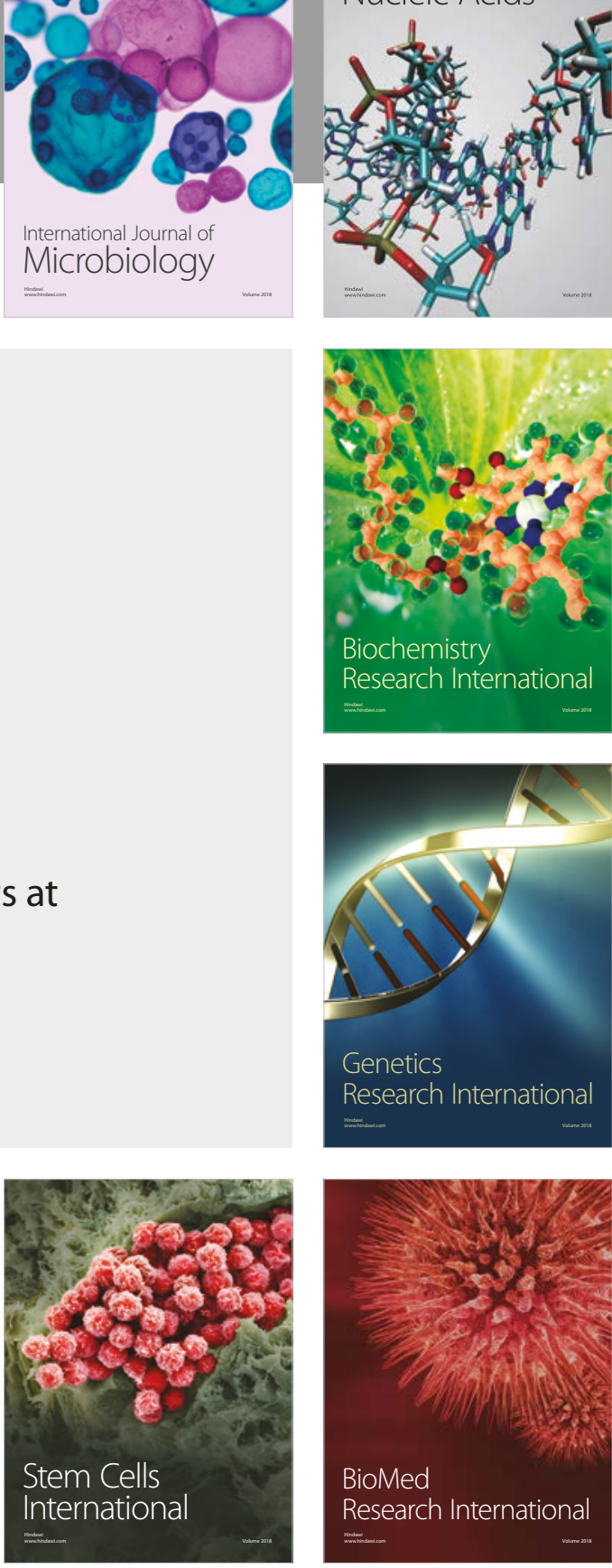
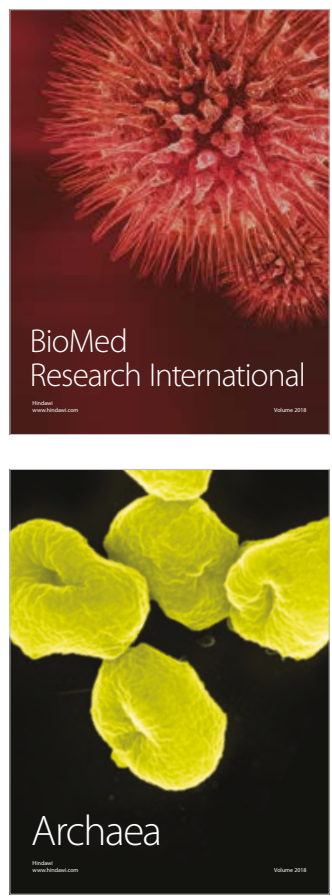